\title{
Éljen Sztálin generalisszimusz! - A digitális történetmesélés első kísérlete az MNL Jász-Nagykun-Szolnok Megyei Levéltárában
}

\section{Long live generalissimus Stalin! - The first experience of digital storytelling in the Jász-Nagykun-Szolnok County Archives of the National Archives of Hungary}

\author{
MUCSI L. ${ }^{1}$, SZABónÉ MASLOWSKi M. ${ }^{2}$ \\ Magyar Nemzeti Levéltár Jász-Nagykun-Szolnok Megyei Levéltára, mucsi.laszlo@mnl.gov.hu \\ Magyar Nemzeti Levéltár Jász-Nagykun-Szolnok $\quad$ Megyei Levéltára, \\ szabone.maslowski.madlen@mnl.gov.hu
}

Absztrakt.

2020-ban a Magyar Nemzeti Levéltár Jász-Nagykun-Szolnok Megyei Levéltára a tartalomközlés új formáját választotta. Az eddigi statikus közlésekkel szemben ezúttal a videógyártás eszközét alkalmazta, amely sokkal inkább kielégíti a mai közönség igényeit. A digitális történetmesélés vizuális és auditiv elemek logikai összefüzésével elöállitott, megosztásra szánt tartalom. Fontosnak tartottuk, hogy az elkészitendö videó középpontjában egy olyan eredeti levéltári irat álljon, amely mind a tartalmat, mind a megjelenést illetöen alkalmas a figyelem felkeltésére. A bemutatásra szánt irategyüttes 1949-ben keletkezett. Iskolás gyermekek dolgozatait és rajzait tartalmazza, amelyek Sztálint köszöntik 70. születésnapja alkalmából. Az irat nemcsak látványos megjelenése, hanem történeti forrásértéke miatt is érdeklödésre tarthat számot. A gyermekek szövegei ugyanis a Sztálin köré épitett vezérkultusz lenyomatai és hüen tükrözik a korszak propagandáját. A videót a YouTube-on publikáltuk.

Kulcsszavak: digitális történetmesélés, Sztálin, vezérkultusz, levéltár

Abstract.

In 2020 Jász-Nagykun-Szolnok County Archives of the National Archives of Hungary tried a new form of presenting. In contrast with the previous static posts, this time Institute used the opportunity of modern video making, which can satisfy the needs of today's audience more successfully. Digital storytelling is such content that is meant to be shared, and is created by the logical connecting of auditory and visual elements. We found it important to place such original archival documents in the centre of the video that are capable of grabbing the attention both with their substance and appearance. The demonstrated documents originate from 1949. They include the texts and drawings of young students, celebrating Stalin's 70th birthday. These documents can appeal to the interest not only by their spectacular appearance but also by their historical value. The children's words are trustworthy proof for Stalin's personality cult and perfectly reflect the propaganda of the era. The video was published on YouTube.

Keywords: digital storytelling, Stalin, personality cult, archives

JEL Kód: 020207 Az új- és jelenkor története

\section{Bevezetés}

A 2020-ban Magyarországon is megjelenő koronavírus járvány gyökeres változást hozott a közgyüjtemények életében. A korlátozások miatt a levéltárak tevékenységének egyes elemei a virtuális

\footnotetext{
${ }^{1}$ ORCID azonosító 0000-0003-2000-3666
}

2 ORCID azonosító 0000-0003-1143-7956 
térbe kényszerültek. Az év nagy részében a látogatók személyesen nem tekinthették meg a Magyar Nemzeti Levéltár Jász-Nagykun-Szolnok Megyei Levéltárának időszaki kiállítását és a levéltárpedagógiai foglalkozásokon sem fogadhattunk gyermekcsoportokat, ezért fontolóra kellett vennünk az online térben való megjelenés lehetőségeit. Ennek voltak már előzményei a levéltárban, a változó felhasználói igények kielégítésének szándéka mégis arra ösztönzött minket, hogy új módszerek megvalósításán kezdjünk gondolkodni. Az MNL 2020 őszi levéltár-pedagógiai továbbképzésén hívták fel figyelmünket a digitális történetmesélés technikájára, melynek megvalósításához szinte rögtön hozzáláttunk. Első videónk elkészítéséhez egy olyan irategyüttest kerestünk, amely tartalma és vizuális megjelenése miatt is számíthatott a közönség figyelmére. Választásunk azokra a dolgozatokra és rajzokra esett, melyeket 1949-ben általános és középiskolás diákok készítettek Sztálin 70. születésnapja alkalmából. Tanulmányunk első felében ezeknek az iratoknak a keletkezési körülményeit mutatjuk be, majd a digitális történetmesélés megvalósításának munkafolyamatát és a közben szerzett tapasztalatokat járjuk körül.

\section{Az iratok bemutatása és keletkezésük körülményei}

Közép- és Kelet-Európa kommunista diktatúráinak közös jellemzője volt a vezérkultusz. ${ }^{3}$ Ez a legtöbb országban nélkülözött minden eredetiséget, a mintát ugyanis maga Joszif Sztálin szolgáltatta a helyi diktátorok számára. ${ }^{4}$ Az ő példáját követve a második világháború után a szovjet érdekszférába került országok kommunista pártjainál is megkezdődött az egyszemélyi vezetők kultuszának építése. ${ }^{5}$ Mivel ezek a pártvezetők és az általuk irányított országok is függő helyzetben voltak a Szovjetunió teljhatalmú urától, ezért egyfajta kettősség alakult ki: egyszerre, egymással szinte párhuzamosan épült Sztálin (és nem mellesleg a nagy elöd, Lenin), valamint a helyi vezetők kultusza. ${ }^{6}$

Magyarországon Sztálint, mint a „felszabadító” Vörös Hadsereg vezetőjét már 1945-től egyfajta tisztelet övezte. Terjedni kezdtek a róla készült képek és szobrok. Kunszentmárton képviselötestülete például 1945. október 9-én határozatot hozott arról, hogy 3000 pengő ellenében megvásárol egy „Sztálin szobrocskát", amely valószínüleg a községházán került elhelyezésre. ${ }^{7}$ 1946-ban születésnapi köszöntő jelent meg a Tiszavidék címü Szolnok megyei napilapban, amelyben már-már emberfelettinek tekinthető attribútumokkal ruházták fel Sztálin személyét. ${ }^{8}$ A nagy vezető és „legjobb magyar tanítványának", Rákosi Mátyásnak kultuszépítése 1948-at követően vett igazán lendületet, miután a Magyar Dolgozók Pártja ténylegesen egyeduralomra tett szert az országban. A Sztálin-kultusz kialakításában nagy jelentősége volt az 1949-es esztendőnek, amikor a „generalisszimusz” 70. születésnapját ünnepelte az ország.

Az ünnepet nem homályosította el, hogy Sztálin valójában nem ekkor töltötte be 70. életévét. A modern történeti irodalomban elfogadott tény, hogy Joszif Visszarionovics Dzsugasvili 1878. december 6-án (a Gergely-naptár szerint december 18-án) látta meg a napvilágot a grúziai Goriban. Születési adatait később 1879. december 9-ére módosította, ezért a világ kommunista felén (már egységesen a Gergelynaptár szerint) 1949. december 21 -én ünnepelték 70. születésnapját. ${ }^{9}$ Azt, hogy a hamisításra miért volt szükség, máig sem tudják a kutatók, az azonban biztos, hogy az évfordulón Magyarország lakói is kitettek magukért.

Ebben az évben Budapesten, a Szikra Kiadó gondozásában 200000 példányban adták ki Sztálin hivatalos életrajzát, míg az életét vizuálisan is bemutató 70 év címü képes albumot 100000 példányban nyomta ki a Hungária Nemzeti Könyvkiadó Vállalat. ${ }^{10}$ A vezető képe felkerült a Magyar Posta által

\footnotetext{
${ }^{3}$ Ezt a szakirodalom személyi vagy vezetőkultusznak is nevezi. A fogalmak használatához a teljesség igénye nélkül lásd: Apor B., 2008. pp. 132.; Gyarmati Gy., 2011. pp. 297.; Pennetier, C., Pudal, B., 2001. pp. 40-41. és Overy, R., 2005. pp. 98-131.

${ }^{4}$ Applebaum, A., 2014. pp. 75.

${ }^{5}$ Pennetier, C., Pudal, B., 2001. pp. 42. Vö: Bottoni, S., 2014. pp. 83.

${ }^{6}$ Applebaum, A., 2014. pp. 75.

${ }^{7}$ Magyar Nemzeti Levéltár Jász-Nagykun-Szolnok Megyei Levéltára (Továbbiakban: MNL JNSzML) V. 627. a. Kunszentmárton nagyközség képviselötestületi jegyzőkönyvei. 138/1945.

${ }^{8}$ Sztálin elvtárs születésnapjának megünneplése. Tiszavidék. II. évf. 101. sz. 1946. december 22. pp. 3.

${ }^{9}$ Kun M., 2002. pp. 19. és Krausz T., 2003. pp. 7.

${ }^{10}$ Gyarmati Gy. 2011. pp. 159. Sztálin hivatalos életrajza meglehetősen későn, csak 1939-ben jelent meg a Szovjetunióban. Magyar nyelven először ugyancsak Moszkvában adták ki a könyvet. Overy, R., 2005. pp. 117-
} 
kiadott bélyegsorozatra, tiszteletére indult első útjára a 70 -es trolibusz Budapesten, ${ }^{11}$ személyével foglalkoztak a vicclapok és a szakmai folyóiratok. ${ }^{12}$ A különböző iparágakban dolgozó munkások ajándéktárgyakat készítettek számára. ${ }^{13} \mathrm{~A}$ városok vezető testületei díszközgyüléseken emlékeztek meg „a haladó emberiség nagy vezére, a béke nagy harcosa” 70. születésnapjáról. ${ }^{14}$ A kisbírók Sztálint dicsöítö szövegeket doboltak ki a falvak föterein. ${ }^{15}$

Az ünnepre való felkészülés természetesen az iskolákat is érintette. Ennek részleteiről számos információval szolgál az az iratcsomó, melyet Jász-Nagykun-Szolnok vármegye tanfelügyelöjének iratai között találtunk meg és amely a digitális történetmesélésre tett első kísérletünk középpontjába került. Az iratokból kiderül, hogy a Vallás- és Közoktatásügyi Minisztérium (VKM) 1949 decemberét a szovjet kultúra hónapjává nyilvánította. A pedagógusok és a diákok feladata az volt, hogy a november 21. és december 21. közötti időszakban felkészüljenek a kulturális hónapot lezáró Sztálin-ünnepségekre. A felkészülés részeként a VKM 1949. november 18-án egy rendeletben részletes javaslatokat tett arra, miként lehet a tanulók Sztálinnal kapcsolatos ismereteit gyarapítani. Meghatározták, hogyan lehet az egyes tantárgyakat erre a célra felhasználni. Az alsó tagozatos diákok például az olvasási órán Sztálinnal és a Szovjetunióval kapcsolatos olvasmányokat dolgozhattak fel, énekórán pedig mozgalmi indulókat énekelhettek. Az iparban és a mezőgazdaságban dolgozókhoz hasonlóan a pedagógusok és a diákok is munkafelajánlásokkal éltek Sztálin tiszteletére. A minisztérium ezekkel a többletmunkákkal kapcsolatban is felvázolta a lehetőségeket. A tanároknak azt javasolta, hogy tartsanak előadásokat szovjet tudósokról és művészekről, valamint ismertessék egymással a Szovjetunió pedagógiai szakirodalmát. A tanulók tanulmányi eredményük és magaviseletük megjavítását is vállalhatták. Az e téren legjobb eredményt elért osztályokat emléklappal jutalmazták. A VKM egy pályázatot is hirdetett a diákok számára. Az általános iskolások írásbeli dolgozatot vagy rajzot, a középiskolások pedig értekezést készíthettek „Mit köszönhet a magyar nép Sztálinnak és a Szovjetuniónak?” címmel. Munkáikat bírálóbizottságok értékelték, a legjobbak pedig megjelentek a Köznevelés címü folyóiratban. ${ }^{16}$

A fent említett iratcsomóban megmaradtak Jász-Nagykun-Szolnok megye iskoláinak legjobb munkafelajánlásai és a pályázatra készített legszebb dolgozatok. Sok tanuló valamilyen Sztálinnal kapcsolatos munkafelajánlást tett: volt, ahol rajzokat készítettek a nagy vezetőről és azzal díszítették az iskola folyosóit, ${ }^{17}$ és akadtak olyan tanulók is, akik a ,Sztálin-dal" megtanulását vállalták. ${ }^{18}$ Sok diák magaviseletének javításával kívánta leróni tiszteletét. Tiszainokai diákok például azt vállalták, hogy nem lopnak és nem cigarettáznak többé. ${ }^{19}$ A pedagógusok munkafelajánlásai általában a Sztálinnal kapcsolatos ismeretek elmélyítését szolgálták. A Kunhegyesi Állami Általános Iskola Fiúkollégiumának nevelői például megfogadták, hogy heti egy órában ismertetik Sztálin életrajzát. ${ }^{20}$ Nehéz megállapítani, hogy a munkát valóban őszinte lelkesedéssel teljesítették-e a diákok és a pedagógusok. Mégis elmondható, hogy a Sztálinról alkotott hivatalos képet minden tanuló alaposan megismerhette, ráadásul azt is megtanulhatták, hogy ő olyan vezető, aki méltó bármilyen áldozathozatalra. Az iskolai munkafelajánlások és azok tervszerü teljesítése tehát az egyik eszköze volt a kultuszépítésnek, eredményessége azonban vitatható.

118. és Alexandrov, G. F., Galaktjionov, M. R., Kruzskov, V. Sz., Mitjin, M. B., Mocsálov, V. D., Poszpjélov, P. N., 1949. pp. 6.

${ }^{11}$ Kun M. 2002. pp. 448-449.

${ }^{12}$ Ludas Matyi. V. évf. 52. sz. 1949. december 22. pp. 1. és Ortutay Gy. 1949. pp. 681-682.

${ }^{13}$ Gyarmati Gy., 2011. pp. 157.

${ }^{14}$ MNL JNSzML V. 271. Kisújszállás város tanácsülési és képviselőtestületi jegyzőkönyvei. 240/1949. 1949. december 20. pp. 153-157.

${ }^{15}$ MNL JNSzML V. 622. c. Öcsöd község közigazgatási iratai. Publikációs könyv. 1949-1950. 1949 december 18. 133. p.

${ }^{16}$ Uo. Az 1200-Sz-1/1949. IV. fö. számú rendelet a Szovjet kultúra hónapja és Sztálin 70. születésnapjának megünneplése tárgyában. 1949. november 18.; Mit köszönhet a magyar nép Sztálinnak és a Szovjetuniónak... Lelkesen köszönti Sztálint a magyar iskolák ifjúsága. Köznevelés. V. évf. 24. sz. 1949. december 15. pp. 696-697. ${ }^{17}$ MNL JNSzML VI. 501. Tanfelügyelő iratai. 5603/1949. A Rákóczifalvi Állami Általános Iskola jelentése a tanulói felajánlásokról. 1949. december 14.

${ }^{18}$ Uo. A Tiszasasi Állami Általános Iskola tanulóinak munkafelajánlása. 1949. november 24.

${ }^{19}$ Uo. A Tiszainokai Általános Iskola munkafelajánlásai. 1949. december 3.

${ }^{20}$ Uo. A Kunhegyesi Állami Általános Iskola Fiúkollégiumának munkafelajánlása. 1949. november 20. 
A „Mit köszönhet a magyar nép Sztálinnak és a Szovjetuniónak?” című pályázatra készített írásbeli dolgozatok és rajzok közös jellemzöje, hogy tartalmazták a korszak közismert történelmi toposzait, melyek Sztálin szerepével és a 20. század eseményeinek megítélésével kapcsolatosak. Ezeket a toposzokat ekkor már 5 éve harsogta a kommunista propaganda, elemei pedig kezdtek meghonosodni az iskolai tananyagban és a történettudományban. A koalíciós időszakban „az iskolai nevelés terén még nem alakult ki világnézeti egyoldalúság, a marxista-kommunista nevelés kötelezösége, az osztályharcos, kirekesztő ideológia. Inkább csak a demokrácia, a szociális egyenlöség kicsit romantikus elképzelése és hirdetése." ${ }^{21}$ A tananyagkészítés marxista fordulata 1948-1949-ben következett be, amikor az oktatás tartalmi átalakításának legfontosabb kérdése a szocializmus melletti egyértelmű politikai állásfoglalás és a marxista-leninista szemlélet érvényesítése lett. 1949 elején már alapelvként fogalmazódott meg, hogy minél gyakrabban szót kell ejteni az iskolákban az aktuális politikai kérdésekről; az elsősöknek is beszélni kellett az ötéves tervről és a munkások hősiességéről, valamint minden korosztályhoz „közel kellett vinni" Lenin, Sztálin és Rákosi Mátyás személyét. ${ }^{22}$ Hamarosan az ehhez tartozó tantervek és tankönyvek is elkészültek. Ami a történetírást illeti, 1945-1948 között a marxista történelemfelfogás ugyan elöretört a polgárival szemben, de csak 1949-ben vette át a vezető szerepet a különböző intézményekben. Az ekkor dolgozó marxista történészek egy új, marxista alapokon álló történelmet írtak, amelyre a személyi kultusz is negatív befolyással volt. ${ }^{23} \mathrm{~A}$,citatológia”, tehát a nagy elődök és vezetők (Marx, Engels, Lenin, Sztálin stb.) állandó idézése kötelező elemévé vált az ekkor született müveknek. ${ }^{24}$ A korszak politikai dogmatizmusa 1949-től folyamatosan megjelent a történelmi munkákban, amelyek sematikusan, leegyszerüsítve és nem ritkán hamisan ábrázolták a különböző történelmi korokat. ${ }^{25} \mathrm{Az}$ általunk bemutatott iskolai dolgozatok is ebben a szellemi klímában készültek és a születésnap miatt a történelmi torzítások kvintesszenciáját tartalmazták.

$\mathrm{Az}$ osztályharcos szemléletet érvényesítve a Horthy-korszakot minden dolgozat igazságtalan, kizsákmányoló rendszerként értékelte, ahol a munkásság vezetöit börtönbe vetették, a dolgozó tömegek pedig elnyomásban és nyomorban éltek. Egy fegyverneki 7. osztályos tanuló szerint „a múlt rendszer csak a tőkések jólétét biztositotta. A munkásság csak azért dolgozott, hogy munkájával egy társadalmi osztály jólétét biztositsa. [...] A hortista Magyarország is csatlakozott és mindenben támogatta a fasisztákat. A szabadságunkért küzdö munkásság vezetöit börtönbe juttatta." ${ }^{26}$ (Sic!) A történeti irodalmat tanulmányozva meg kell állapítanunk, hogy ezek a gondolatok megfeleltek a korszak felfogásának. ${ }^{27}$ Jól tetten érhető a gyermekek szövegeiben az a történelemkönyvekben is megjelenő állítás, mely szerint a magyar népet a vezetői kényszerítették a Szovjetunió megtámadására, ám Sztálin felismerte ezt, ,felvilágositotta a szovjet katonákat, hogy a magyar nem ellenség”, és barátsággal fordult a magyar emberek felé. ${ }^{28}$ A gyermekek ismeretei szerint az elnyomásból a „dicsőséges Szovjet Hadsereg” és annak „,bölcs vezetője”, Sztálin szabadította fel az országot. Döntései nyomán nemcsak az újjáépítést koronázta siker, hanem addig soha nem látott gazdasági, társadalmi és kulturális fejlődés vette kezdetét. ${ }^{29}$ A bolsevik történeti narratíva logikájának megfelelően a diákok az eseményeket általában Sztálin személyén keresztül mutatták be: minden Sztálinnak köszönhető, mindent ő irányít és

\footnotetext{
${ }^{21}$ Kardos J., 2007. pp. 27.

${ }^{22}$ Knausz I., 1994. pp. 46.

${ }^{23}$ Fischer, H., 2012. pp. 12.

${ }^{24}$ Erös V., 2013. pp 57.

${ }^{25}$ Fischer, H., 2012. pp. 13.

${ }^{26}$ MNL JNSzML VI. 501. Tanfelügyelő iratai. 5603/1949. Fegyverneki diák dolgozata 1949. december 13.

${ }^{27}$ Mód A., 1951. pp. 458. p. A magyar történetírás fent megállapított periodizációját jól szemlélteti, hogy Mód Aladár 400 év küzdelem az önálló Magyarországért című könyvének 1948-as kiadása még sokkal kevésbé volt tarkított a marxista túlzásokkal. Lásd: Mód A., 1948. pp. 188-207. Mód Aladár könyvével kapcsolatban lásd: Szöts Z. O., 2014.
}

${ }^{28}$ MNL JNSzML VI. 501. Tanfelügyelő iratai. 5603/1949. Tiszasülyi 8. osztályos tanuló dolgozata. Annak a hangsúlyozása, miszerint a magyar népet csak vezetői kényszerítették a Szovjetunió megtámadására, már 1941ben elkezdődött. A Szovjetunióban müködő Kossuth-rádióban hangzott el 1941. november 14-én, hogy „A magyar nép nem akart háborút, sem „,keresztest”, sem megelőzőt. A magyar nép békét akart. Áruló urai mégis háborút kezdtek. Ök kezdték, de a magyar nép fogja befejezni.” Idézi: Ádám M., Juhász Gy., Kerekes L., 1959. pp. 350.

${ }^{29}$ A valóság az volt, hogy bár a háború után a Szovjetunió valóban támogatta Kelet-Európa iparosítását, előtte azonban a Vörös Hadsereg részt vett Magyarország kirablásában, sőt Sztálin háborús jóvátételt követelt az általa megszállt országoktól. Lásd: Applebaum, A., 2014. pp. 68-69. 
minden pozitív fordulat az ő döntéseinek az eredménye. ${ }^{30}$ Ha valaki említést is tett a szovjet katonák „,hősiességéről”, a Magyar Kommunista Párt szerepéről vagy az ötéves tervről, gyorsan hozzátette, hogy minden siker az ő géniuszának köszönhető, nélküle soha nem sikerült volna legyőzni a németeket, megteremteni a békét és fejlődési pályára állítani az országot. ${ }^{31}$ Hivatalos életrajzához hasonlóan mitikus személyként ábrázolták és többek között „, a szovjet hösök hösének”, „szabadságunk megszerzöjének”, „a világ legnagyobb emberének”, az „orosz nép nagy tanitójának”, „az egész haladó emberiség vezérének” és ,a magyar nép nagy barátjának” titulálták. ${ }^{32} \mathrm{Az}$ iránta érzett hála is óriási mértéket öltött. Egy mesterszállási tanuló már-már imára emlékeztető sorokkal zárta dolgozatát: „Kérünk téged kedves Sztálin elvtárs, hogy ezután is maradj jó barátunk, vezérelj továbbra is bennünket. Ezért kivánjuk, hogy még sok de nagyon sok és boldog évet eljél bekességben kedves Sztálin elvtárs." ${ }^{33}$ (Sic!)

A dolgozatok annyira pontosan tartalmazták a korszak propagandájának elemeit, hogy a kutatóban felmerülhet a kétely, hogy ezeket a szövegeket valóban gyermekek írták-e. Technikailag biztosan, erről az íráskép és a gyakori helyesírási hibák is árulkodnak. A bennük olvasható panelek megjelentek az oktatásban és valószínűleg többször elhangzottak a szovjet kultúra hónapján is, ennek ellenére valószínűnek tartjuk, hogy a tanulók erőteljes tanári segítséget kaptak a dolgozatok megírásakor. Mindenesetre az iratcsomó jól illusztrálja, hogy a kultuszépítés milyen mélyen áthatotta a magyar közoktatást 1949-ben. Sztálin valóban mintaként szolgált Rákosi számára, amit mi sem bizonyít jobban, minthogy 1952-ben, a magyar diktátor születésének 60. évfordulóján az iskolás gyermekek ismét munkafelajánlásokkal éltek és dolgozatokat írtak „Miért szeretik a gyerekek Rákosi elvtársat?”, valamint „Mit köszönhet a magyar ifjúság Rákosi elvtársnak?” címmel. ${ }^{34}$ Sztálin 1953-ban bekövetkezett haláláig kultuszának építése töretlen maradt és meghatározta Magyarország mindennapjait.

\section{Ötlettől a megvalósításig - A digitális tartalomgyártás lépései}

Jogosan merül fel a közmüvelődéssel, ismeretterjesztéssel is foglalkozó levéltáros fejében a kérdés, hogy mit kezdjen egy ilyen - reményei szerint - közérdeklődésre is számot tartó iratcsomóval. Hol, milyen módon és eszközökkel szólíthatja meg a legszélesebb közönséget, hogyan érheti el a legnagyobb figyelmet és milyen célkitüzést szeretne ezáltal megvalósítani? Tanulmányunk második felében ezekre a kérdésekre keressük a választ.

A levéltárak az elmúlt évtizedben a „nyitott vagy szolgáltató levéltár koncepciójának” köszönhetően egyre több adattartalmat szolgáltattak önkéntesen. Korábban elsősorban az ügyfeles megkereséseket, azaz a közigazgatási feladatokat, valamint a kutatók szakszerü kiszolgálását tekintették általános levéltári feladatnak. Emellett a levéltárosok saját kutatási területükön elért legújabb eredményeiket szakmai kiadványokban és konferenciákon tárták a közönség elé. 2005-től a közművelődési feladatok szélesedésével már a történelem iránt érdeklődő nagyközönség megszólítása is határozott célként szerepelt. ${ }^{35}$ Ezek elsődleges eszközei a levéltári anyagot feldolgozó tematikus kiállítások, valamint az ismeretterjesztő előadások voltak. Az internet és a levéltári anyagok digitalizálásának térhódítása következtében egyre nagyobb mennyiségü adattartalom került a világhálóra, melyeket számítógépről és mobiltelefonról is elérhetett a felhasználó.

A távoli hozzáférés előnyeinek felismerése ellenére az MNL Jász-Nagykun-Szolnok Megyei Levéltárában 2019-ig az elsődleges célkitüzés a kutatókkal és látogatókkal való személyes kapcsolat megteremtése volt. Úgy gondoltuk, hogy raktár-, vagy tárlatvezetések, valamint konferenciák keretei között tudjuk a legtöbb és leghitelesebb információt átadni tevékenységünkröl, miközben lehetőség nyílik az interakcióra is. Az időszaki kiállítások külső helyszínekre történő kihelyezése, valamint a helyi városi televízióban 2016-ban indított ismeretterjesztő sorozatnak köszönhetően sokszorosára duzzadt a

\footnotetext{
${ }^{30}$ Apor B., 2008. pp. 132-136.

${ }^{31}$ MNL JNSzML VI. 501. Tanfelügyelö iratai. 5603/1949. Egy tomajmonostori diák dolgozata. 1949. december 6.

${ }^{32}$ MNL JNSzML VI. 501. Tanfelügyelő iratai. 5603/1949. Több dolgozat.

${ }^{33}$ Uo. Egy mesterszállási diák dolgozata. 1949.

${ }^{34}$ Kelemen E., 2007. pp. 69.

${ }^{35}$ Simonkay M. 2017
} 
befogadók száma, viszont egyoldalúvá vált a kommunikáció iránya. A levéltári értékközvetítésre ugyanis nem érkezhetett egyidejű válasz vagy reakció. Ugyanez volt a helyzet a levéltár korábbi honlapján megtalálható hírfolyammal, valamint a „Hónap dokumentuma” rovattal is. Új korszak kezdődött 2010 szeptemberében, amikor elindult a levéltár első Facebook-oldala, amely közel 1600 követőt vonzott. Évente átlagosan 160, zömében statikus tartalmat (újságcikkeket, linkeket, meghívókat) osztottunk meg, ami a legnépszerübb közösségi platformnak hála, már az interaktivitásra is lehetőséget biztosított. Az online felületen közzétett tartalmakat a látogatók kommentálhatják, véleményezhetik vagy akár meg is oszthatják, melyek nagyban hozzájárulnak az elérések növekedéséhez. ${ }^{36} \mathrm{Az}$ intézményi közösségi oldal statisztikai adatainak köszönhetően nemcsak a látogatók földrajzi, életkori és nembeli megoszlásáról kaphatunk pontos képet, hanem az egyes posztjaink népszerüségét is figyelemmel kísérhetjük. Ezek az adatok mára fontos elemeivé váltak az intézmény év végi munkabeszámolójának.

Köztudott, hogy a követők érdeklődését nehéz fenntartani. A közösségi média folyamatosan megújuló trendjeinek következtében kénytelenek voltunk korábbi eszköztárunkat frissíteni. Emellett tartalomszolgáltatásunk formai megújulásában más tényezők is fontos szerepet játszottak. Az új típusú koronavírus járvány miatt Magyarország Kormánya 2020. március 11-én az ország egész területére veszélyhelyzetet hirdetett ki. ${ }^{37}$ Dr. habil. Szabó Csaba, a Magyar Nemzeti Levéltár főigazgatója 2020. március 13-tól visszavonásig elrendelte az MNL valamennyi kutatóhellyel rendelkező telephelyén a kutatótermek bezárását, valamint a megyei levéltár-igazgatók felelősségére bízta a levéltári rendezvények és az intézménylátogatások kockázatának mérlegelését. ${ }^{38}$ A veszélyhelyzet 2020. június 18-i megszüntetését ${ }^{39}$ követően július 1-vel - a megfelelő védőintézkedések betartása mellett - a levéltárak is visszatérhettek hagyományos tevékenységükhöz. ${ }^{40}$ Sajnos a látogatószám messze elmaradt a korábban megszokottól. A veszélyhelyzet 2020 . november 4-i újbóli kihirdetésével, ${ }^{41}$ valamint a kulturális szférára vonatkozó részletszabályokkal ${ }^{42}$ újból a virtuális világba helyeződött át az intézmény közmüvelődési és ismeretterjesztő tevékenysége. A tartalomszolgáltatás megújulásának ötletét a Magyar Nemzeti Levéltár 2020. október 20-i belső levéltár-pedagógiai továbbképzésén Hecker Henrietta előadásából merítettük. ${ }^{43}$ A digitális történetmesélést bemutató prezentációjában kolléganőnk elsősorban a módszer diákok általi megvalósításáról beszélt. A felvetésből kiindulva megvizsgáltuk, hogy a technikáját felhasználva, de a kommunikációs csatornát megfordítva, hogyan tudnánk értéket közvetíteni közönségünknek.

A digitális történetmesélés nem más, mint információs és kommunikációs eszközökkel illusztrált rövid (2-10 perces) elbeszélés. A gyakorlatban vizuális és auditív elemek logikai összefüzésével előállított, megosztásra szánt tartalom. Szakértők szerint 2020-ban a közösségi platformok legdinamikusabban fejlődő és legtöbb követőt megmozgató tartalmai a videók voltak. Nem véletlenül, hiszen a videók gyorsabban képesek egységnyi információt átadni, mint az írott szó, ráadásul sokkal hatékonyabban ragadják meg a felhasználók figyelmét. Ezzel is magyarázható, hogy bár a YouTube klasszikus értelemben nem sorolható a közösségi médiaplatformok sorába, ám a felület aktív felhasználóinak számát figyelembe véve mégis az előkelő 2 . helyet foglalja el (a Facebookot követve) ${ }^{44}$ Az oldalon

36 https://bluemarketing.hu/marketing-blog/kozossegi-media-marketing-2020-ban-ezeket-a-platformokatveletlenul-se-keruld-ki/?cn-reloaded $=1$

${ }^{37}$ 40/2020.(III.11.) Korm. rendelet

38 2/2020. (03.02.) sz. Főigazgatói utasítás

${ }^{39}$ 282/2020. (VI.17.) Korm. rendelet

${ }^{40} 15 / 2020$. (06.24.) sz. Főigazgatói utasítás

${ }^{41} 478 / 2020$. (XI.3.) Korm. rendelet

42 479/2020. (XI.3.) Korm. rendelet

${ }^{43}$ Hecker H. 2020.

${ }^{44}$ 2019. évi felmérések adatai alapján a magyar népesség több mint fele (56,8\%) megtalálható a Facebookon, míg a YouTube-nak 4454000 aktív felhasználója van hazánkban. Forrás: https://www.digitalhungary.hu/kozossegimedia/Mutatjuk-hogy-kinek-milyen-kozossegi-media-platformot-erdemes-hasznalnia-marketingjehez-2020ban/9283/ 
regisztrálók követhetik az általuk figyelemmel kísért megosztók tartalmait, tetszésüket vagy nemtetszésüket fejezhetik ki, valamint kommentelhetnek, cseveghetnek a videók alatt. Statisztikai adatok alapján elmondható, hogy a világ legnagyobb keresőmotorjával ellátott felületet a 40 év alatti korosztály használja legnagyobb számban. ${ }^{45}$

Levéltárunk munkatársaitól korábban sem állt távol, hogy egy-egy dokumentumot, vagy irategyüttest élvezhető formában, kifejezetten a nagyközönség számára mutassanak be. Intézményi honlapunkon elindított és immár 10 éves múltra visszatekintő „Hónap dokumentuma” rovatunk ${ }^{46}$ havi rendszerességgel közöl változatos témában rövid, közérthető írásokat. 2016 novemberében a Szolnok Televízió önálló müsort indított „Levéltári kincseink” címmel. A 8-10 perces magazinnal a levéltár sokszínű gyüjteménye iránt kívánták felkelteni a tévénéző közönség érdeklődését. A 24 részt megélt müsorfolyam epizódjai az internetre is felkerültek, ${ }^{47}$ a helyi tévében pedig a mai napig folyamatosan ismétlik azokat. A sorozat végét a televízió kapacitáshiánya okozta, de meg kell említenünk, hogy a feladat a levéltárosokat is aránytalanul nagy kihívás elé állította, hiszen még az előadások tartásához hozzáedződött kollégákat is feszélyezte a kamera jelenléte. A digitális történetmeséléssel tulajdonképpen e két korábbi sorozatunk előnyeit ötvözhettük, hátrányait viszont kiküszöbölhettük. Mivel Hecker Henrietta előadása a megvalósítással kevésbé foglalkozott, először az interneten fellelhető ismertetőkből, tanulmányokból, ${ }^{48}$ illetve digitális történetekböl ${ }^{49}$ igyekeztünk felmérni, milyen infrastruktúrára és kompetenciákra van szükség tervünk sikeres végrehajtásához.

A téma kiválasztása nem okozott gondot, hiszen a Sztálin születésnapjára készült dolgozatokat tartalmazó iratcsomót már korábban megtaláltuk és eredetileg a hónap dokumentumaként kívántuk felhasználni. A digitális történetmesélés müfaji kereteit és megjelenési formáját viszont sokkal kedvezőbbnek találtuk a hagyományos, egyedi fotókkal, vagy fotógalériával illusztrált publikációnál, ezért úgy döntöttünk, hogy egy audiovizuális produktumot készítünk belőle, melyet feltöltünk a levéltár YouTube-csatornájára, valamint közzéteszünk az intézmény hivatalos és Facebook-oldalán. Maga a levéltári forrás bőségesen tartalmazott vizuálisan jól bemutatható dokumentumokat és rajzokat. Ezeket a későbbiekben a világhálóról (például az Arcanum Digitális Tudománytárból és a Fortepan közösségi fotóarchívumból) letöltött, valamint korábban nyomtatásban megjelent ${ }^{50}$ illusztrációkkal színesítettük. A szerzői jogokat tiszteletben tartva a képek forrásait a megosztott videó leírásában hivatkoztuk meg. ${ }^{51}$ Mondanivalónk szövegének lejegyzésekor több nehézségünk támadt: az első változat túl hosszúra sikerült, ezért kb. egyharmadával rövidíteni kellett rajta annak érdekében, hogy hangos felolvasása sem haladja meg az 5 percet. Annak ellenére, hogy a gyermekek munkafelajánlásai is érdekes információkat tartalmaztak, bemutatásukat kénytelenek voltunk kihagyni a videóból. Azzal a problémával is szembesültünk, hogy a történet szóban való elmesélése más megfogalmazást és mondathosszúságokat igényel, mint az írott szöveg. Felismertük, hogy ajánlatos a nyelvtörő szavak, szóösszetételek mellőzése, az alá- és mellérendelések, bővítmények mértéktelen használatával pedig az elbeszélő tüdőkapacitását tesszük fölöslegesen próbára. A szöveg megfelelő minőségü rögzítése is többszöri próbálkozást követően sikerült, az egyszerü diktafon ugyanis meglepően érzékenynek bizonyult és a hanganyag hátterében tisztán kivehető volt a levéltárban folyó mindennapos tevékenység, vagy az ablakokon beszürődő forgalom zaja. Az elkészült hangfájlt ingyenes hangszerkesztő program segítségével tisztítottuk meg a zavaró sistergéstől.

Történetmesélésünk alapkoncepciója az volt, hogy a források legkifejezőbb részeiből olvasunk fel idézeteket, melyeket történelmi tényeket, érdekességeket tartalmazó narrációval magyarázunk. A

\footnotetext{
${ }^{45}$ Uo.

${ }^{46} \mathrm{https}: / / \mathrm{mnl} . \mathrm{gov} \cdot \mathrm{hu} / \mathrm{mnl} / \mathrm{jnszml} / \mathrm{hirek} / \mathrm{erdekes}$ iratok

${ }^{47}$ https://www.youtube.com/playlist?list=PLQ6CtT63JCIX6LDq9C0B6diAkZ-uv5Hx2

${ }^{48}$ A téma hazai kutatójának és szakértőjének, Dr. Lanszki Anitának a munkái megkerülhetetlenek.

${ }^{49}$ https://digitalistortenetmeseles.hu/digitalis-tortenetek/

${ }^{50}$ Például Alexandrov, G. F., Galaktjionov, M. R., Kruzskov, V. Sz., Mitjin, M. B., Mocsálov, V. D., Poszpjélov, P. N., 1949.

${ }^{51}$ A személyiségi jogokat tiszteletben tartva a dolgozatokat anonimizáltuk a megjelenítéskor.
} 
digitális történetmesélés klasszikus módszere, mely szerint a mesélő egyes szám első személyben interpretál egy személyes élményt, nem bizonyult alkalmasnak ahhoz, hogy korábbi korok történeteit bemutassuk. Ezért választottuk azt a lehetőséget, hogy egy kívülálló (jelen esetben a levéltáros) szemszögéből, levéltári források segítségével beszéljük el a múlt eseményeit. Így azonban nagyon nehéz megfelelni a digitális történetmesélés egyik fő kritériumának, a személyes érintettségnek. Ebben az esetben ezt úgy próbáltuk biztosítani, hogy olyan iratokat helyeztünk a középpontba, amelyek tágabb lakókörnyezetünk mindennapjainak történetébe engednek betekintést, amely reményeink szerint lehetővé teszi, hogy a felhasználók könnyen átélhessék a rekonstruált eseményeket. Az idézeteket és a narrációt két egymástól jól elkülöníthető (női és férfi) hang alkalmazásával tettük egyértelművé. Az egyszerüség kedvéért a történetet egyetlen felvételen rögzítettük, kiküszöbölve a vágásokkal és illesztésekkel járó többletmunkát. A hangfelvétel hossza megadta a készülő videó időintervallumát is, így a szöveget szakaszoltuk, mappákba rendeztük az egyes részekhez illeszkedő képeket, majd pontosan meghatároztuk időzítésük helyét a forgatókönyvben. Első kísérletünk kivitelezését a Microsoft PowerPoint diabemutató szoftver segítségével valósítottuk meg. Mozgóképes tartalmak előállításában idáig nem volt tapasztalatunk, de tudtuk, hogy ez a program alkalmas arra, hogy az egyes diák közötti áttünési effektusok kinézetének és sebességének testre szabásával szinkronba hozzuk képi mondanivalónkat a hanganyaggal, mindezt pedig a munkafolyamat végén videóvá konvertálhatjuk.

Az első videó elkészítése közben már annak tudatában dolgoztunk, hogy egy egész sorozatot szeretnénk indítani a digitális történetmesélés módszerére támaszkodva. Az újonnan induló sorozat a „(Köz)történetek” címet viseli. Az első megosztást megelőzően beharangozóval igyekeztünk hivatalos intézményi és Facebook-oldalunk követőinek érdeklődését felkelteni az új tartalom iránt. ${ }^{52}$ Ajánlónkban olyan történetek bemutatását ígértük, amelyek reményeink szerint szórakoztató formában járulnak hozzá történelmünk megismeréséhez. ${ }^{53} \mathrm{~A}$ széria elindításának kinyilatkoztatásával tulajdonképpen még azelőtt elköteleződtünk a soron következő tartalmak elkészítése mellett, mielőtt konkrét visszajelzésünk lett volna a célközönségtől. Mindenesetre bíztunk videónk kedvező fogadtatásában.

Digitális történetünket 2020. december 18-án „Éljen Sztálin generalisszimusz!” címmel élesítettük a YouTube-csatornánkon. ${ }^{54} \mathrm{~A}$ feltöltés napján a nézők száma elérte a 100 főt, a tanulmány megírásáig ${ }^{55}$ mindösszesen 243-an tekintették meg első videónkat. A közösségi oldalakon statisztikázott interakciók ugyan nem haladták meg a szokásos számot (ez átlagban az elérések 10\%-a), ám a megtekintések mennyisége $\mathrm{kb}$. a háromszorosa volt a korábbi statikus posztoknak. A folytatás sikeressége - úgy véljük - digitális kompetenciáink fejlesztésén múlik.

Első videós megjelenésünk előállítása hosszadalmas munkafolyamat eredményeként született meg, melyben a legtöbb időt a technikai megvalósítás igényelte. A szövegalkotási és megjelenítési problémákon túlmutatott a digitális eszközhasználati gyakorlatlanságunk. Nyilvánvalóan nem lehet célunk felvenni a versenyt a professzionális videós tartalomgyártókkal, mégis úgy érezzük, hogy a levéltárunk állományában szép számban fellelhető, eddig publikálatlan iratanyag garanciát biztosít arra, hogy a magunk eszközeivel is egyedi, értékes produktumokat állítsunk elő. A kísérletben résztvevők feltett szándéka, hogy a történetmesélés újabb perspektíváit próbálják ki, új megoldásokon dolgozzanak, annak érdekében, hogy elkerüljék az első audiovizuális kísérlet sematikus ismétlésének hibáját, és saját tanulási folyamataikon keresztül próbáljanak az újfajta ismeretterjesztés kihívásainak megfelelni.

\section{Irodalomjegyzék}

2/2020. (03.02.) sz. Főigazgatói utasítás az új típusú koronavírus járvánnyal kapcsolatos rendkívüli intézkedésekről a Magyar Nemzeti Levéltárban.

15/2020. (06.24.) sz. Főigazgatói utasítás az MNL kutatótermeinek újranyitásával és az iratkezelési feladatok ellátásával kapcsolatban

\footnotetext{
${ }^{52} \mathrm{~A}$ közművelödési intézmények sikeres müködéséhez is elengedhetetlen a tervszerü PR tevékenység.

${ }^{53} \mathrm{https} / / / \mathrm{mnl} . g o v \cdot h u / \mathrm{mnl} / \mathrm{jnszml} / \mathrm{hirek} /$ koztortenetek

${ }^{54} \mathrm{https} / / / \mathrm{www}$. youtube.com/watch? $\mathrm{v}=66$ O1xDd3I8

552021.01 .12$.
} 
40/2020.(III.11.) Korm. rendelet veszélyhelyzet kihirdetéséröl. 2021. 01. 05.

282/2020. (VI.17.) Korm. rendelet a 2020. március 11-én kihirdetett veszélyhelyzet megszüntetéséröl. 2021. 01. 05.

478/2020. (XI.3.) Korm. rendelet a veszélyhelyzet kihirdetéséről. 2021. 01.05.

479/2020. (XI.3.) Korm. rendelet a veszélyhelyzet idején alkalmazandó további védelmi intézkedésekröl. 2021. 01. 05.

Ádám M., Juhász Gy., Kerekes L. (szerk.) (1959): Magyarország és a második világháború. Titkos diplomáciai okmányok a háború elözményeihez és történetéhez. Kossuth Könyvkiadó, Budapest.

Alexandrov, G., F., Galaktjionov, M., R., Kruzskov, V., Sz., Mitjin, M., B., Mocsálov, V., D., Poszpjélov, P., N., (1949): Joszif Visszarionovics Sztálin. Rövid életrajz. Szikra Kiadás, Budapest.

Apor B. (2008): Hagiográfia és kommunista vezérkultusz: Rákosi Mátyás életrajzai. In: Horváth S. (szerk.) (2008): Mindennapok Rákosi és Kádár korában. Új utak a szocialista korszak kutatásában. Nyitott Könyvmühely, Budapest. pp. 132-153.

Applebaum, A. (2014): Vasfüggöny. Kelet-Európa megtörése 1944-1956. Európa Könyvkiadó, Budapest.

Bottoni, S. (2014): A várva várt Nyugat. Kelet-Európa története 1944-töl napjainkig. [Magyar Történelmi Emlékek, Értekezések] MTA Bölcsészettudományi Kutatóközpont Történettudományi Intézet, Budapest.

https://digitalistortenetmeseles.hu/digitalis-tortenetek/. 2021. 01.07.

https://mnl.gov.hu/mnl/jnszml/hirek/erdekes_iratok. 2020.01.07.

Erős V. (2013): A magyar történetírás 1945 után. Valóság, 56. évf. 10. szám: pp. 48-74.

Fischer, H. (2012): Történetírás a szocialista Magyarországon - Periodizációs kísérlet külső szemszögből. In: Erős V., Takács Á. (szerk.): Tudomány és ideológia között. Tanulmányok az 1945 utáni magyar történetírásról. [Talentum Sorozat 13.] ELTE Eötvös Kiadó, h. n. pp. 10-21.

Gyarmati Gy. (2011): A Rákosi-korszak. Rendszerváltó fordulatok évtizede Magyarországon, 1945 1946. ÁBTL-Rubicon, Budapest.

Hecker H. (2020): Digitális történetmesélés mint levéltár-pedagógiai módszer (belső képzésen elhangzott elöadás)

Kardos J. (2007): Iskola a politika sodrásában. (1945-1993.) Gondolat Kiadó, Budapest.

Knausz I. (1994): A közoktatás Magyarországon 1945-1956. Kandidátusi disszertáció. A disszertáció kéziratának digitalizált változata. https://mek.oszk.hu/10000/10080/10080.pdf. 2020. szeptember 15 .

https://bluemarketing.hu/marketing-blog/kozossegi-media-marketing-2020-ban-ezeket-a-platformokatveletlenul-se-keruld-ki/?cn-reloaded=1. 2021. 01. 05.

https://mnl.gov.hu/mnl/jnszml/hirek/koztortenetek. 2021. 01.06.

Krausz T. (2003): Sztálin élete és kora. Pannonica Kiadó, h. n.

Kun M. (2002): Az ismeretlen Sztálin. Atheneum 2000 - PolgArt, Budapest.

Lanszki A. (2017): A digitális történetmesélés mint tanulásszervezési eljárás tanulástámogató és kompetenciafejlesztő hatása az oktatási folyamatban. Doktori disszertáció. https://ntdi.unieszterhazy.hu/public/uploads/lanszki-anita-doktori-e-rtekeze-s-munkahelyi-vita_5a6b05b3e1929.pdf.

2021. 01. 05.

Ludas Matyi, V. évf. 52. szám: 1949. december 22. pp. 1.

Mit köszönhet a magyar nép Sztálinnak és a Szovjetuniónak...Lelkesen köszönti Sztálint a magyar iskolák ifjúsága. Köznevelés, V. évf. 24. szám: 1949. december 15. pp. 696-697.

Mód A. (1948): 400 év küzdelem az önálló Magyarországért. Szikra Kiadás, Budapest.

Mód A. (1951): 400 év küzdelem az önálló Magyarországért. Szikra Kiadás, Budapest.

https://www.digitalhungary.hu/kozossegi-media/Mutatjuk-hogy-kinek-milyen-kozossegi-media-

platformot-erdemes-hasznalnia-marketingjehez-2020-ban/9283/. 2021. 01.05.

Novák K. (2018): Digitális történetmesélés és digitális történetek https://education.microsoft.com/huhu/course/9e2ea05a/4. 2021. 01.06.

Ortutay Gy. (1949): Sztálin: a legnagyobb nevelö. Köznevelés, V. évf. 24. szám: 1949. december 15. pp. 681-682.

Overy, R. (2005): The Dictators. Hitler's Germany, Stalin's Russia. Penguin Books, London.

Pennetier, C., Pudal, B. (2001): Sztálinizmus, munkáskultusz és vezetőkultusz. Rubicon, 2001/4-5. szám: pp. $40-42$. 
Simonkay M. (2017): Levéltár-pedagógia ma és holnap. Levéltári Szemle, 67. évf. 4. szám: pp. 53. Szőts Z. O. (2014): Mód Aladár és a „,400 év küzdelem” mitosza. http://ujkor.hu/content/mod-aladares-a-400-ev-kuzdelem-mitosza. 2021. 01.05.

Sztálin elvtárs születésnapjának megünneplése. Tiszavidék, II. évf. 101. szám: 1946. december 22. pp. 3.

https://www.youtube.com/playlist?list=PLQ6CtT63JCIX6LDq9C0B6diAkZ-uv5Hx2. 2020. 01. 06. https://www.youtube.com/watch?v=66_O1xDd3I8. 2021. 01.06. 